\title{
The Impact of Debt Capacity on Firm's Growth: (A Case Study of Selected Firms from Pharmaceutical Industry in Pakistan)
}

\author{
IHTESHAM KHAN \\ Assistant Professor, Abdul Wali Khan University, Mardan \\ ihtishamkhan@awkum.edu.pk \\ SYED WAQAR AHMAD SHAH \\ MBA Student, Abdul Wali Khan University, Mardan \\ ASAD KHAN \\ Lecturer, University of Haripur, Haripur
}

\begin{abstract}
The ultimate goal of all activities within organizations is to achieve higher growth and finding new sources for mounting firm capital. This study aims to investigate debt capacity as the source of firm capital and its impact on firm's growth. The objectives of this research to shows the relationship between market to book ratio and debt to asset ratio. Multiple liner regression is used between Growth and book leverage. By selected pharmaceutical sector that has been listed at Karachi stock exchange in Pakistan. In this research 8 companies are selected that are listed at Karachi Stock Exchange during the period of 2005-2014. In this paper secondary data is used. The result reveals a significant positive relationship between the debt to asset ratio and market to book ratio and debt to asset ratio. It displays that there is no negative effect of debt capacity on firm's growth.
\end{abstract}

Keywords: Firm's Growth, Debt Capacity; Market to Book ratio, Debt to Asset ratio

\section{Introduction}

Company' growth and capital structure play important role in firm success as it shows stability and profitability of firm in long run. Every company set the capital structure policy according to their nature and size of company but most of the firm's arrange lower debt portion than equity because its reduce the chances of bankruptcy and minimized risk. Debt capacity is the ability of borrowing money and deals those funds that a firm can borrow from lenders. The choice of debt in capital structure for attaining loans is the issue for the corporate policy maker, because there are no patterns for the proportion of debt in capital structure. There are many factors which taking in to consideration before any decision regarding debt. Most of researchers argued that firms use low level of debt in capital structure during their growth stage of life cycle. In some cases, organization does not have the ability to borrow funds from lenders as much they 
want. There are many factors that influence the borrowing but I concern the main factor the company growth because debt and growth are highly depended on each other's if the firm growth is on the roadway their debt level will be high and if the firm growth level decreases then their debt level will be low. It is repeatedly argued that companies use fewer debts in their capital structure during their growth stage of life cycle. (Rajan \& Zingales (1995), Billet et al. (2007), Smith \& Watts, (1992). As acknowledged by Ittner et al. (2003), new economy companies are smaller; follow more riskier strategies, which have expressively lesser accounting returns, and new enterprises more expenses such as, advertising, broad research and development than old economy firms. Financing decision differs across firms to firm as a purpose of their life cycle stages. Smith and Watts (1992) and Gaver (1993) found that multinationals have lesser debt to equity ratio in the life cycle of growth stage. Rajan and Zingales (1995) found adverse relationship between market to book ratio and the leverage while taken the growth as a proxy, and result is statistically significant across seven countries. Billet et al. (2007) documented that, firm growth is directly moves to the corporate debt in an adverse direction. Scholars have only in recent times revealed that capital structure changes express information to stockholders. This discussion emphasis on the concerns related to debt capacity and firm's growth. The scope of our study is directly linked with these concerns to find out the mutual impact of these factors in pharmaceutical industry of Pakistan. Reason behind choosing this industry is that there are more than 400 licensed pharmaceutical corporations in Pakistan, including 30 multinational corporations that have more than 50 $\%$ of total market share. Pakistan pharmaceutical sector totally worth is roughly 1.90 billion US dollar with an annual $9.4 \%$ of growth rate.

\subsection{Research Question}

Study will examine the relation between debt capacity and growth of firms?

\section{Literature Review}

Earlier investigation in the subject area Michael et al (2003) shown a negative relationship between growth and leverage and provides a different economic explanation of leverage regressions. Bradley et al (1984) show that firms low level of debt have high growth rate. Smith and Watts (1992) and Long and Malitz (1985) commonly used proxy for growth options and all has found a negative relationship between the market-to-book ratio and market leverage. Zingales and Rajan (1995) studied across seven countries and bring into being a negative relationship between market to book ratio and leverage. Frasmo and Joseph (2013) found that there is a significant and strong positive relationship between debt capacity and growth used a regression base result with evidence from quasi natural experiment in pharmaceutical industry. Johnson (2003) shown that there is negative relation between firm's growth and debt and further argued that high use of debt may lead high liquidity risk, using the data of 4,945 nonfinancial firms from 1986_1995, this study support strongly Myer's estimates that short term obligation has inverse impact on growth of firm. Gaver and Gaver (1993) displayed preliminary evidence that growth firm uses lesser amount of debt in their capital structure. Goyal et al. (2002) concluded that defense firms of United State boost their use of debt as growth declines. Billet et al. (2007) shows that firm growth are directly 
affected by the corporate debt in an inverse direction. Johnson (2003) displayed that there is inverse relation between debt capacity and growth of firm. They also discussed that small period obligation has an adverse effect of growth on debt by giving a proof that short term debt leads high liquidity of risk and that risk adversely affects book leverage. Athar et al (2012) found a significant and strong positive relation between growth of firm and leverage(debt to asset ratio). Yusof and Bahlous (2012) used a sample of 1588 firms from the East Asia during the period 1999 to 2007. They examined the relationships between growth and debt maturity of external financing. Lemmon and Zender (2003) found that if outside funds are required to firm, in the absenteeism of debt capacity concerns, debt seems to be favored on equity. Giambona and Golec (2013) regression results displayed that there is a significant and strong positive relationship between growth and debt. Huang and song's (2001) analyzed market and accounting data of 1000 companies listed in Shanghai stock exchange to show the effect of leverage in Chinese firms. The study revealed that more stable firms in term of size and fixed assets used more debt while reduce the debt level low profitability and correlates with other industries. They further argued that levered firm effect ownership structure of firms. Chaibi (2012) studied the industry impact on financing growth. "According to overinvestment as well as underinvestment problem, companies are additional probable to have a smaller portion debt in their growth period of life cycle.

Ezeoha (2008) investigate the significance of firm size as a determinant of financial leverage and found negative relation between them. Hes and Kotter explore empirically the link between debt capacity and corporate financing decisions of a firm. Their analysis and result documented that firms target on preserve financial flexibility provides debt capacity. Stephen et al (2011) concluded debt in a moderate level, they argued that debt improves welfare funds for corporate social responsibility and increases the firm growth while increasing the levels of debt can be damaging the firm value and increase chances of bankruptcy. Barclay et al (2003) results and analysis revealed that there is an inverse relationship between leverage and growth.

\subsection{Hypotheses}

$\mathrm{H}_{0}$ : There is a relationship between firm growth and debt capacity.

$\mathrm{H}_{1}$ : There is a relationship between firm growth and market price per share.

\section{Research Methodology}

Scientific and logical procedure is known as Methodology. This chapter deals with methodology that has been used for carrying out this research. The methodology is just a method of organization that building theoretical and practical activity. The study focuses on empirically analyzing the impact of debt capacity on firm growth. This data of this research paper is totally based on secondary data. The data of this research is bring together from the (SBP)State Bank of Pakistan publications statement of comprehensive income and balance sheet analysis and also used internet sources as well as company annual report of Pharmaceutical sector selected companies listed at Karachi stock exchange during the period of 2005 to 2014. State Bank of Pakistan publication delivers valuable information of the financial statements analysis of pharmaceutical sector selected corporations listed at Karachi stock exchange and stock prices of selected 
companies has been taken from annual reports of specific company, share price considered as yearend. In this study, first analysis and interpretation is descriptive statistics and correlation among all variables and recognized their significant relationship. Then analyzed and assesses the data in multiple linear regression models.

$\mathrm{MTB}=\beta \mathrm{o}+\beta_{1}(\mathrm{DTA})+\beta_{2} \mathrm{MPS}+\varepsilon$.

\subsection{Nature and Source of Data}

In this research paper secondary data is used for the period of 2005-2014

\subsection{Sources of Data Collection}

Data were collected from different sources and from different website, such aswww.businessrecorder.com, http://www.answers.com/topic/abbott-laboratories and open door.com. Books and annual report of different companies are also used for data collections. This research is totally based on secondary data.

\subsection{Data Processing}

For data processing analysis I used SPSS software and other statistical tools namely, descriptive statistic ,correlation as well as regression analysis and excel has always been used for data processing.

\subsection{Regression Model}

To find the relationship in the middle of debt capacity and firm growth using the multiple linear regression model done by pervious researchers Rajan and Zangal (1995) as well as correlated with the model discussed by Athar et al (2014). The regression model is estimated as below:

$$
\mathrm{MTB}=\beta \mathrm{o}+\beta_{1}(\mathrm{DTA})+\beta_{2} \mathrm{MPS}+\varepsilon .
$$

Where $\mathrm{MTB}=$ Market to Book Ratio, $\beta \mathrm{o}=$ constant term of model, DTA $=$ dividend per share, MPS $=$ market price per share and $\varepsilon=$ error term

\subsection{Variable Define}

Variables for the model of this study are explained below

\subsubsection{Growth}

In this paper, market-to-book ratio (MTB) is used for measuring and calculating the growth of the firm, for the reason that it shows the total market value of firms by matching and comparing the book value of company and it is calculated by year end share price multiple by outstanding shares divide by Share Holder's Equity. Wu, Sercu (2001), A. Johnson (2003), Mao (2003) and Chi (2006) also used this ratio.

Formula: MTB = Year end Share price * outstanding shares / Share Holder's Equity

\subsubsection{Book Leverage (Debt to Asset Ratio)}

The debt to asset ratio (DTA) is defined as the current plus noncurrent assets divide by short term and long term liabilities. For calculating and measuring the debt capacity (debt to asset ratio) was used. Debt to asset ratio indicates the portion of a business's assets which is received to corporation through debt. Suhaila, and Mahmood (2008), as well as Dittmar (2004) also used this ratio in their studies.

Formula: DTA = Total Debt / Book value of Assets.

\subsubsection{Market Price per Share (MPS)}

(MPS) Market price for each share considered as an independent variable which can be taken directly from company annual report for specific year, as the year end share 
price.

\subsection{Sample Size}

In this paper secondary data is used and collected from annual report of the 08 out of 10 listed companies on Karachi Stock from official and relevant website.

\section{Table2: 4.1 Descriptive Statistics}

Table 4.1 shows the descriptive analysis of variables which is statistically includes minimum value, maximum value, means and standard deviation, while $\mathrm{N}$ representing total number of observations. As we know that mean shows the average value of total observation while standard deviation shows variation among data.

\begin{tabular}{|c|c|c|c|c|c|}
\hline & $\mathrm{N}$ & Minimum & Maximum & Mean & Std. Deviation \\
\hline \multirow{5}{*}{$\begin{array}{l}\text { debt to asset } \\
\text { market to book } \\
\text { market price } \\
\text { Valid N (list wise) }\end{array}$} & 80 & .02 & 3.76 & .4298 & .45828 \\
\hline & 80 & 71.08 & 6399.77 & 2.3674E3 & 1574.39461 \\
\hline & 80 & 28.35 & 4500.00 & $4.0766 \mathrm{E} 2$ & 809.09514 \\
\hline & & & & & \\
\hline & 80 & & & & \\
\hline
\end{tabular}

The first variable is debt to asset, which is independent variable. The means is .4298; standard deviation is 45828 minimum values are.02and maximum value is 3.76 . The second variable is MTB and it is dependent variable which means is 2.3674E3, minimum value is 71.08 , its maximum value is 6399.77 and standard deviation is 1574.39461. The third variable is MPS which is also independent and its means is $4.0766 \mathrm{E} 2$, standard deviation is 809.09514 , minimum value is 28.35 and maximum value is 4500 .

Table 3: 4.2 Correlations:

The interdependency between two or more than two variables is called correlation. The correlation shows the directional relationship among variables. The direction may be negative or it's may be positive.

\begin{tabular}{|llll|}
\hline & Debt to asset & Market to book & Market price \\
\hline Debt to asset & 1 & & \\
Market to book & .188 & 1 & 1 \\
Market price & -.079 & $.317^{* *}$ & 1 \\
\hline
\end{tabular}

Table 4.2 shows the co-relation among dependent and independent variables. The analysis of data and result revealed that firm's growth and debt capacity is significantly and positively related. It shows that firm growth increase with the increasing of debt. The relationship between firm's growth and market price is negative. It shows that market price decrease firm growth will be increase. 


\subsection{Regression Analysis and Hypothesis Testing}

The dependency of one variable (dependent variable) upon another variable (independent variable is known as regression. It shows the relationship between variables. Regressions which have one independent variable are called simple linear regression. In the same way, a regression containing two or over independent variables is known as multiple linear regression. In this study I used multiple linear regressions. The following table shows the regression result.

Table 4.3.1: Model summary

\begin{tabular}{|l|l|l|l|l|}
\hline Model & $\mathrm{R}$ & $\mathrm{R}$ Square & $\begin{array}{l}\text { Adjusted } \\
\text { Square }\end{array}$ & $\begin{array}{l}\text { Std. Error of } \\
\text { the Estimate }\end{array}$ \\
\hline 1 & $.382^{\mathrm{a}}$ & .146 & .124 & 1473.63621 \\
\hline
\end{tabular}

From the above table the result reveals that the value of $\mathrm{R}$ square is .146 which indicates the two independent variables that used in this study explained 14.6 variations in the dependent variable, which indicates other factor that influence firm growth which is not study in this paper is 85.4. Further study can be conducted to examine other factor which has impact on firm growth.

Table 4.3.2: Analysis of Variance

\begin{tabular}{|ll|ll|l|l|l|l|}
\hline Model & & $\begin{array}{l}\text { Sum } \\
\text { Squares }\end{array}$ & of & Df & Mean Square & F & Sig. \\
\hline 1 & Regression & $2.861 \mathrm{E} 7$ & 2 & $1.430 \mathrm{E} 7$ & 6.586 & $.002^{\mathrm{a}}$ \\
& Residual & $1.672 \mathrm{E} 8$ & 77 & 2171603.674 & & \\
& Total & $1.958 \mathrm{E} 8$ & 79 & & & \\
\hline
\end{tabular}

a. Predictors: (Constant), market price, debt to asset

b. Dependent Variable: market to book

ANOVA shows the overall model fitness. From the above table I conclude that the significance value .002 and $\mathrm{F}$ value is 6.586 which indicates that the model is statistically significant to predict the effect of debt to assets and market price per share on firm growth.

Table 4.3.3: Regression Coefficient

\begin{tabular}{|c|c|c|c|c|c|c|}
\hline \multirow{2}{*}{\multicolumn{2}{|c|}{ Model }} & \multicolumn{2}{|c|}{ Unstandardized Coefficients } & \multirow{2}{*}{$\begin{array}{l}\text { Standardized } \\
\text { Coefficients } \\
\text { Beta }\end{array}$} & \multirow[b]{2}{*}{$\mathrm{t}$} & \multirow[b]{2}{*}{ Sig. } \\
\hline & & B & Std. Error & & & \\
\hline \multirow[t]{3}{*}{1} & (Constant) & 1786.067 & 246.103 & & 7.257 & .000 \\
\hline & debt to asset & 736.469 & 362.921 & .214 & 2.029 & .046 \\
\hline & market price & .650 & .206 & .334 & 3.160 & .002 \\
\hline
\end{tabular}

$\mathrm{MTB}=\beta \mathrm{o}+\beta_{1}(\mathrm{DTA})+\beta_{2} \mathrm{MPS}+\varepsilon$.

$\mathrm{MTB}=1786.067+736 \mathrm{DTA}+.650 \mathrm{MPS}$

The above equation shows that an intercept value is 1786.067 . It shows that if the 
value of all independent variables are taken constant at 0 the firm growth will be1786.067. Where B1 value is 736 which indicates that if debt to asset change by 1 unit the firm growth will be change by 736 units if all other variable are held constant. Therefore the paper found the significant and direct relationship between growth of firm and debt capacity. This relationship is significant at 5\% level of significance. In this study, the hypothesis which has been developed is accepted. Where B2 value is .650 which shows that if MPS increase by one unit and other predictor are constant the value of firm growth will be.650. The result is significant at 5\% level of significant. In this study, the developed hypothesis is accepted.

\section{Conclusion}

This research paper is all about of debt capacity and their effect on firm growth. The finding of this study, I conclude and found that debt capacity is significantly and positively related with growth of firms in pharmaceutical sector selected companies listed at Karachi stock exchange and therefore the hypothesis which I developed in methodology is accepted. This study further shows that if a corporation debt level decreasing or increasing; there will be no inverse effect on the growth of firms. This study consists of three variables. Growth is considered as an dependent variable and market price per share as well as debt to asset ratio both are taken as independent variables. In this research, on yearly basis 10 years secondary data is used of selected companies. For data analysis descriptive statistics, correlation and Regression model is used. The study developed hypothesis that there is significant and positive relation among debt capacity and firm growth and my findings are supported by the analysis of Minjina (2008; Sercu \& X.wu, 2001).

\section{References}

Al-Najjar, B., \& Taylor, P. (2008). The relationship between capital structure and ownership structure: New evidence from Jordanian panel data. Managerial Finance, 34(12), 919-933.

Ambrose, B. W., Cordell, L. R., \& Ma, S. (2015). The impact of student loan debt on small business formation.

Arnold, N., \& Dagher, J. C. (2010). Growth and Strategic Savings. Available at SSRN 1664076.

Bahlous, M., \& Yusof, R. M. (2012). Financing patterns, debt maturity and growth: Evidence from East Asia and the GCC Countries. Journal of Applied Finance and Banking, 2(3), 199.

Barclay, M. J., Morellec, E., \& Smith, C. W. (2001). On the debt capacity of growth options. Simon School of Business Working Paper No. FR, 01-07.

Berger, P., Ofek, E., \& Yermack, D. (1997). Managerial entrenchment and capital structure decisions. Journal of Finance, Vol. 52, pp.1411-38.

Bhabra, H. S., Liu, T., \& Tirtiroglu, D. (2008). Capital structure choice in a nascent market: Evidence from listed firms in China. Financial Management, 37(2), 341364.

Booth, L., Aivazian, V., Demirguc-Kunt, A., \& Maksimovic, V. (2001). Capital structures in developing countries. Journal of Finance, Vol. 1, pp.87-130.

Campello, M. (2006). Debt financing: Does it boost or hurt firm performance in product 
markets?.Journal of Financial Economics, 82(1), 135-172.

Çekrezi, A. (2013). Impact of firm specific factors on capital structure decision: an empirical study of Albanian firms. European Journal of Sustainable Development, 2(4), 135.

Chaibi, H. (2014). Adverse Selection, Debt Capacity And Corporate Growth: An Industry Life Cycle Perspective. Journal of Applied Business Research, 30(1), 173.

Chowdhury, A., \& Chowdhury, S. P. (2010). Impact of capital structure on firm's value: Evidence from Bangladesh. Business and Economic Horizons, 3(3), 111-122.

Dittmar, A. (2004). Capital Structure in Corporate Spin-Offs, Journal of Business, 77(1).

Ebel, E., A. (2008). Firm size and corporate financial-leverage choice in a developing economy: Evidence from Nigeria. The Journal of Risk Finance, 9(4), 351-364.

Ganguli, S. K. (2013). Capital structure-does ownership structure matter? Theory and Indian evidence. Studies in Economics and Finance, 30(1), 56-72.

Giambona, E., \& Golec, J. (2012). The growth opportunity channel of debt structure. Available at SSRN.

Hameed, I., Iqbal, A., \& Ramzan, N. (2012). The Impact of Debt Capacity on Firm's Growth. American Journal of Scientific Research, (59).

Harris, M., \& Raviv, A. (1990). Capital structure and the informational role of debt. Journal of Finance, Vol. 45 pp.321-49.

Heisz , A., \& Larochelle.(2004). Corporate financial leverage in Canadian manufacturing: Consequences for employment and inventories. Business and Labor Market Analysis, Division.

Hess, D., \& Immenkötter, P. (2014). How much is too much? Debt Capacity and Financial Flexibility. Debt Capacity and Financial Flexibility (March 2014).

Hoo, Y. k., Mira., \& Mang, C. (2006). Size, Leverage, Concentration and R\&D Investment in Generating Growth Opportunities. Journal of Business, 79(2).

Huang, G. (2006). The determinants of capital structure: Evidence from China. China Economic Review, 17(1), 14-36.

Huang, S.G., \& Song, F.M. (2006). The determinants of capital structure: evidence from China. China Economic Review, Vol. 17 pp.1-23.

Hussain, I. (2011). Growth and Financing Behaviour of Firms of Textile Industry in Pakistan: A Panel Data Analysis. The Pakistan Development Review, 699-714.

Javid, A. Y., \& Imad, Q. (2012). A Decomposition Analysis of Capital Structure: Evidence from Pakistan's Manufacturing Sector. The Lahore Journal of Economics, 17(1), 1.

Jensen, M., \& Meckling, W. (1976). The theory of the firm: managerial behaviour, agency costs, and ownership structure", Journal of Financial Economics, Vol. 3 pp.305-60.

Johnson, S. A. (2003). Debt Maturity and the effect of Growth Opportunities and liquidity risk on Leverage, The Review of Financial Studies, 16(1), 209-236.

Kiran, S. (2013). Determinants of Capital Structure: A Comparative Analysis of Textile, Chemical \& Fuel and Energy Sectors of Pakistan (2001-2006). International Review of Management and Business Research, 2(1), 37.

Leland, H. E., \& Pyle, D. H. (1977). Informational asymmetries, financial structure, and 
financial intermediation. The Journal of Finance, Vol. 32 pp.371-87.

Lemmon, M. L., \& Zender, J. F. (2010). Debt capacity and tests of capital structure theories.

Mao, C. X. (2003). Interaction of Debt Agency Problems and Optimal Capital Structure Theory and Evidence, The Journal of Financial and Quantitative Analysis, 38(2),399-423

Marchica, M. T., \& Mura, R. (2010). Financial flexibility, investment ability, and firm value: evidence from firms with spare debt capacity. Financial management, 39(4), 1339-1365.

Masulis, R. W. (1980). The effects of capital structure change on security prices: A study of exchange offers. Journal of financial economics, 8(2), 139-178.

Miller, M.H., \& Kevin, R. (1985). Dividend policy under asymmetric information. The Journal of Finance, Vol. 40, pp.1031-51.

Modigliani, F., \& Miller, M. (1963). Corporate income taxes and the cost of capital: a correction analysis. American Economic Review, Vol. 53 pp.433-43. , The Financial Review, Vol. 33 pp.85-98.

Modigliani, F., \& Miller, M.H. (1958). The cost of capital, corporation finance and the theory of investment. American Economic Review, Vol. 48 pp.261-97

Moore, W., \& Thomas, C. (2010). A meta-analysis of the relationship between debt and growth. International Journal of Development Issues, 9(3), 214-225.

Myers, S. C. (1984). The capital structure puzzle. The journal of finance, 39(3), 574-592.

Myers, S.C., \& Majluf, N.S. (1984). Corporate financing and investment decisions when firms have information that investors do not have. Journal of Financial Economics, Vol. 13, pp.187-221.

Nishat, M. (2000).The Systematic Risk and Leverage Effect in the Corporate Sector of Pakistan. The Pakistan Development Review, 39(4), 951-962.

Qureshi, M. A., Akhtar, W., \& Imdadullah, M. (2012). Does diversification affect capital structure and profitability in Pakistan?.Asian Social Science, 8(4), 30.

Rajan, R.G., \& Zingales, L. (1995). What do we know about capital structure? Some evidence from international data. Journal of Finance, Vol. 50 pp.1421-60.

Titman, S., \& Wessels, R. (1988). The determinants of capital structure choice. Journal of Finance, Vol. 43 pp.1-19.

Ullah, H., e Saqib, S., \& Usman, H. (n.a). The Impact of Dividend Policy on Stock Price Volatility: A Case Study of Selected Firms from Textile Industry in Pakistan.

Wu, X., \& Sercu, P. (2001). Reexamining the Relation between Debt Mix and Growth.Department of Economics and Finance, City University of Hong Kong. 